\title{
Does Cesarean Section on Request Protect Women from Sexual Dysfunction Later in their Life
}

\author{
A Faúndes ${ }^{* 1,2}$ and L Miranda ${ }^{1,2}$ \\ ${ }^{1}$ Department of Obstetrics and Gynecology, Faculty of Medicine, Brazil \\ ${ }^{2}$ Center for Research in Human Reproduction of Campinas (Cemicamp), Brazil \\ *Corresponding author: Anibal Faúndes, Department of Obstetrics and Gynecology, Faculty of Medicine, Brazil
}

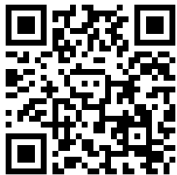

\begin{tabular}{ll}
\hline ARTICLE INFO ABSTRACT \\
\hline
\end{tabular}

Received: 㓞 February 12, 2019

Published: 蔧 February 26, 2019

Citation: A Faúndes, L Miranda. Does Cesarean Section on Request Protect Women from Sexual Dysfunction Later in their Life. Biomed J Sci \& Tech Res 15(2)-2019. BJSTR. MS.ID.002660.
Keywords: Elective Cesarean Section; Vaginal Delivery; Perineal Trauma; Female Sexual Function; Male Sexual Function

\section{Background}

Cesarean section is a life saving intervention, which contribute to reduce neonatal and maternal morbidity and mortality when the evolution of pregnancy and delivery is not normal. In countries where there still are regions with lack of conditions to carry out cesarean section, mothers and newborns still die for obstructed labor [1]. With the progressive improvement of surgical technique and methods of anesthesia, the safety of this surgical procedure has greatly improved, which has made that many obstetricians consider cesarean delivery as safe or safer than vaginal delivery. For many decades the rates of cesarean delivery remain below 15 and 10\%, with broad variations between countries, It was by the last couple of decades of the 20th century that the cesarean section rates started to increase exponentially in some countries, as specifically occurred in Brazil, where it has reached nearly $90 \%$ of deliveries among private health security patients [2].

The main reason given for that very high $\mathrm{C}$ section rate is that women request that form of delivery and obstetricians just accept the women's right to decide their preferred form of delivery. They recognized, however, that obstetricians felt that the long duration and unpredictability of vaginal birth, which are not paid according to the longer hours of work associated with attend ing spontaneous vaginal delivery, contribute to the high caesarean section rates [2].

In fact, women request an elective cesarean delivery based in the information they received from different sources, but the most important source of information is their attending obstetrician. Many obstetricians are not interested in promoting vaginal birth for the reason described above, and they tend to convince their patients to accept an elective cesarean programmed before the 39th week of gestation to prevent a spontaneous labor, which will interfere in his or her normal routines [3]. In fact. convenience for the doctor and also for the patients, is also accepted as an importat determinant of the increase in elective cesarean rate [4]. Although fear of pain during labor and delivery may be the most important reason to select elective cesarean, another important reason given by women who request elective cesarean section for all their parturitions is that by that means they will be protected from vaginal and perineum damage, which may cause sexual dysfunction after birth and for the rest of their lives [4-6].

Many doctors agree with that protective effect of C-Section on request [7] and that opinion influences the women's decision to request an elective cesarean delivery. Considerng that a 
cesarean section is associated with increased risks for the mother and the neonate $[8,9]$, it is very important to revise if an elective cesarean section has in fact, a protective effect against later sexual dysfunctions.

\section{Mode of Delivery and Sexual Function}

There is no doubt that vaginal birth can lead to disruption of the perineal structures, which may be more severe with instrumental vaginal birth. A number of studies have shown that the prevalence of dyspareunea, accompanied by other sexual dysfunctions, is increased according to the severity of the perineal trauma, being maximal after operative vaginal delivery $[10,11]$. All these problems are minimal among women having and elective cesarean or a vaginal birth with minimal or no perineal trauma. Thus, any comparison of dyspareunea and sexual function in the first six months post-partum between elective cesarean and vaginal birth will find poorer results for the vaginal birth, depending on the proportion of operative vaginal delivery and the severity of eventual perineal trauma.

The most severe perineal injuries can have long term consequences for sexual function. A study carried out in Germany found that women with third/fourth degree anal sphincter tear had a significantly higher risk of not being sexually active one year after delivery in comparison with those with minimal or not perineal trauma. [12]. With that exception, sexual function beyond six month after delivery shows very little if any difference between women who delivered vaginally and those who delivered by cesarean including elective C section. [13-15]. There is one study , however, which found that the women who had vaginal delivery with medio-lateral episiotomy demonstrated a trend toward higher prevalence of dissatisfaction in all subscales of sexual function, without reaching statistical significance [16]. We found only one study comparing of male sexual function accrding to their wives form of delivery, which found a non-significant lower proportion of sexual disatfaction among husband of women who had vaginal delivery than among husband of women who had only cesarean, concluding that women should not be induced to have a cesarean to prevent sexual problems with their husband [17]. Thus, the review of the literature leave no doubt that the prevention of sexual disfunction should not be a reason to select elective cesarean as mode of delivery, while, at the same time, all efforts should be done to prevent severe perineal trauma during vaginal delivey.

\section{References}

1. Harrison MS, Griffin JB, McClure EM, Jones B, Moran K, et al. (2016) Maternal Mortality from Obstructed Labor: A MANDATE Analysis of the
Ability of Technology to Save Lives in Sub-Saharan Africa. Am J Perinatol 33(9): 873-881.

2. Galvao R, Hawley NL, Da Silva CS, Silveira MF (2018) How obstetricians and pregnant women decide mode of birth in light of a recent regulation in Brazil. Women Birth 31(5): e310-e317.

3. Potter JE, Hopkins K, Faundes A, Perpetuo I (2008) Women's Autonomy and Scheduled Cesarean Sections in Brazil: A Cautionary Tale. BIRTH 35(1): 33-40.

4. Wax JR, Cartin A, Pinette MG, Blackstone J (2004) Patient Choice Cesarean: An Evidence- Based Review. Obstetrical and Gynecological Survey 59(8): 601-616.

5. Bracken JN, Dryfhout VL, Goldenhar LM, Pauls RN (2008) Preferences and concerns for delivery: an antepartum survey. Int Urogynecol J 19(11): 1527-1531.

6. Cai L, Zhang B, Lin H, Xing W, Chen J (2014) Does vaginal delivery affect postnatal coitus? Int J Impot Res 26(1): 24-27.

7. Klein MC (2012) Cesarean section on maternal request: a societal and professional failure and symptom of a much larger problem. Birth 39(4): 305-310.

8. Steer PJ, Modi N (2009) Elective caesarean sections--risks to the infant. Lancet 374(9691): 675-676.

9. Blustein J, Liu J (2015) Time to consider the risks of caesarean delivery for long term child health. BMJ 10: 350 .

10. Signorello LB, Harlow BL, Chekos AK, Repke JT (2001) Postpartum sexual functioning and its relationship to perineal trauma: A retrospective cohort study of primiparous women. Am J Obstet Gynecol 184(5): 881890 .

11. Buhling KJ, Schmidt S, Robinson JN, Klapp C, Siebert G, et al. (2006) Rate of dyspareunia after delivery in primiparae according to mode of delivery. European Journal of Obstetrics \& Gynecology and Reproductive Biology 124(1): 42-46.

12. van Brummen $H$, Bruinse $H$, van de Pol G, Heintz A, van der Vaart C (2006) Which factors determine the sexual function 1 year after childbirth? BJOG 113(8): 914-918.

13. Dazhi Fan, Song Li, Wen Wang, Guo Tian, Li Liu, et al. (2017) Sexual dysfunction and mode of delivery in Chinese primiparous women: a systematic review and meta-analysis. BMC Pregnancy and Childbirth 17: 408.

14. Barrett G, Peacock J, Victor CR, Manyonda I (2005) Cesarean Section and Postnatal Sexual Health. Birth 32(4): 306-311.

15. Hannah ME, Whyte H, Hannah WJ, Hewson S, Amankwah K (2004) Maternal outcomes at 2 years after planned cesarean section versus planned vaginal birth for breech presentation at term: The international randomized. Term Breech Trial. Am JObstet Gynecol 191(3): 917-927.

16. Gungor S, Baser I, Ceyhan S, Karasahin E, Acikel CH (2007) Mode of delivery and subsequent long-term sexual function of primiparous women. International Journal of Impotence Research 19(4): 358-365.

17. Gungor S, Baser I, Ceyhan T, Karasahin E, Kilic S (2008) Does mode of delivery affect sexual functioning of the man partner? J Sex Med 5(1): 155-163. 
ISSN: 2574-1241

DOI: 10.26717/BJSTR.2019.15.002660

Anibal Faúndes. Biomed J Sci \& Tech Res

(C) This work is licensed under Creative

Submission Link: https://biomedres.us/submit-manuscript.php

$\begin{array}{ll}\text { BIOMEDICAL } & \text { Assets of Publishing with us } \\ \text { RESEARCHES } & \text { - Global archiving of articles } \\ \text { - Immediate, unrestricted online access } \\ \text { - Rigorous Peer Review Process } \\ \end{array}$

